\title{
Teaching Geoheritage Values: Implementation and Thematic Analysis Evaluation of a Synchronous Online Educational Approach
}

\author{
Efthymios Georgousis ${ }^{1, *(D)}$, Maria Savelidi ${ }^{2}$, Socrates Savelides ${ }^{3}$, Maximos-Vasileios Holokolos 4 (D) \\ and Hara Drinia ${ }^{1}$ D \\ 1 Department of Geology and Geoenvironment, National and Kapodistrian University of Athens, \\ 15784 Athens, Greece; cntrinia@geol.uoa.gr \\ 2 Faculty of Economics and Business, University of Ghent, 9000 Ghent, Belgium; maria.savelidi@ugent.be \\ 3 Hellenic Ministry of Education and Religious Affairs, Directorate of Secondary Education of Magnesia, \\ 38333 Volos, Greece; ssavelidis@uth.gr \\ 4 Department of Culture, Creative Media and Industries, University of Thessaly, \\ 38221 Volos, Greece; mcholokolos@uth.gr \\ * Correspondence: egeorgousis@geol.uoa.gr
}

check for updates

Citation: Georgousis, E.; Savelidi, M.; Savelides, S.; Holokolos, M.-V.; Drinia, H. Teaching Geoheritage Values: Implementation and Thematic Analysis Evaluation of a Synchronous Online Educational Approach. Heritage 2021, 4, 3523-3542. https://doi.org/10.3390/heritage 4040195

Academic Editors: Dmitry A. Ruban and Miguel Gomez-Heras

Received: 30 August 2021

Accepted: 13 October 2021

Published: 16 October 2021

Publisher's Note: MDPI stays neutral with regard to jurisdictional claims in published maps and institutional affiliations.

Copyright: (c) 2021 by the authors. Licensee MDPI, Basel, Switzerland. This article is an open access article distributed under the terms and conditions of the Creative Commons Attribution (CC BY) license (https:// creativecommons.org/licenses/by/ $4.0 /)$.

\begin{abstract}
The purpose of this article is to present the results of an environmental education program on "Storm-Tossed Sea Rocks in Pelion Seaside" designed for junior high school students and implemented as a synchronous online educational approach and with a main goal to empower students to the values of geoheritage. In order to examine the effectiveness of the program and in particular the achievement of the objectives that encourage the development of values, the research question was identified as to whether the implementation of the environmental program achieved the empowerment of students in geoheritage values. In order to answer this question, we implemented a rather unusual technique to evaluate the educational procedure, which was based on the qualitative research technique of thematic analysis. This technique was selected as the most appropriate in order to "mine" conceptual patterns, the analysis of which would, in a valid, reliable, and simultaneously easy to use and quick way, inform the teachers that the values of geoheritage were disseminated to the students through the program. Thus, four-question interviews were conducted with randomly selected students who participated in the program. The data were examined and conceptual patterns were identified which were classified in eighteen codes. The codes were divided into five categories, the analysis of which led to the answer to the research question. Thus, it was found that the implementation of the environmental program achieved the empowerment of students in geocultural heritage values. The development of feelings of environmental sensitivity has also been seen, which suggests further investigation is needed. It was concluded that for the students, the given educational approach was necessary as well as cognitively, pedagogically, and emotionally beneficial; therefore, the need to enrich the curricula of environmental education/education for sustainable development with issues of geodiversity and geocultural heritage is justified. Finally, what was ascertained is that the thematic-analysis-based evaluation technique of the educational procedure, which was implemented, provided the teachers with the requested information, and it is recommended as an evaluation technique of educational procedures which aim at empowering students on values - even for daily use in school.
\end{abstract}

Keywords: geocultural heritage; environmental education; qualitative thematic analysis

\section{Introduction}

In Greece, the links between geology and culture are particularly strong, and the last decade has seen the onset of more intense exploration of geocultural heritage. According to the Implementation of the UNECE Strategy for Education for Sustainable Development 
"Greece places particular emphasis on achieving sustainable development and is strongly committed to the implementation of the 2030 Agenda for Sustainable Development ... [and] ... the Hellenic Ministry of Education is promoting policies and measures at all education levels, for the integration of the basic principles of sustainable development" [1]. However, in the Greek educational system, the teaching of geology is deficient in the subject of geosciences and geoenvironment [2], and the cognitive content of environmental education, which is based on the voluntary participation of students and teachers, fails to refer to the field of geological heritage, resulting in the lack of reflection on the particular problems which arise when this subject with the needs to geocultural heritage understanding and geoethical awareness. Moreover, relevant research on students of secondary and tertiary education showed that the education of students in geodiversity and geoheritage is significantly degraded; the integration of geoeducation in environmental education (geoenvironmental education) is proposed [3] as well as the strengthening of geological heritage with holistic approaches and interdisciplinary connections [4] (p. 32).

In order to empower students in the knowledge, skills, values, and attitudes [5] of geocultural heritage, via the dissemination of these values, an educational environmental program was held for a period of one year regarding the geocultural heritage of the rocky coast landforms of Pelion entitled "Storm-Tossed Sea Rocks in Pelion Seaside". For the effectiveness of the program, the research question concerning the achievement of students' empowerment in geoheritage values was identified. Since the educational circumstances demanded a valid and reliable and mainly quick evaluation on the "sensitive" issue of values transfer to the students by the teachers, the research technique of thematic analysis was selected as an evaluation method, making use of a small number of participant students, as well as a small number of targeted questions. Interviews were conducted with randomly selected participant students. The data were examined, and conceptual patterns were identified, which were classified in eighteen codes, which were then divided into five categories, the analysis of which led to the answer of the research question.

\section{The Values of Geocultural Heritage}

Individuals, in their lives, seek to achieve goals and display attitudes, beliefs, and behaviors that appear to be significantly influenced by guiding principles, which are characterized here as values [6] (p. 2). A person's values concerning the environment reflect their rational perception of that, namely their set of ideas, views, and concepts about the environment [7] (p. 947). It is possible to empower individuals in environmental values which can prove to be a key factor-action in order to address environmental issues and problems and achieve sustainable development [7] (p. 948).

Confirming the above, in relation to environmental values education and more generally for environmental education sustainability (EEFS), Tilbury [8] (p. 201) states: "A value is a certain belief, attitude or conviction that is consistently reflected in one's behavior. Values determine decisions and actions and are thus of great consequence to environmental education. EEFS is not limited to teaching about values but extends to the teaching of values required for sustainable living".

The geological heritage is part of the environmental context, and its protection is an important factor of sustainability development. Characteristically, Carreras and Druguet, on geological heritage, point out that: geological heritage is an essential part of World heritage, as it constitutes the unique record of the whole evolution of our planet. The Earth's evolution is recorded in a huge number of pieces ... Protecting geological objects [these pieces] requires protection of the sites where the objects are located, and this can only be achieved by accommodating the planning and management to the existing environments, where the distinction of natural and non-natural sites becomes senseless [9] (p. 95).

Correlating the above, we could support that it is crucial, both for resolving environmental issues, as well as for achieving sustainable development, to educate our young people on the values of geocultural heritage. 
Many values of the natural world are related to geology. These geological values refer to the geological history, geological phenomena, and geological processes. For these to be perceived, geological knowledge is needed, which is why geology should contribute to the dissemination of geological data knowledge of scientific and didactic interest [10]. A lack of geological knowledge hinders the understanding of geological value [3]. An important aspect of geological knowledge is the dimension of geological time governing the earthly processes. Researchers of science education have not placed much importance to geology time [11], even though humans are usually unable to comprehend the time scale of natural processes [3], which provides information on events that have taken place in the past. So, in order to understand the geological value, it is necessary to emphasize students' grasp of the significance of geologic time [12], in order for them to understand the dimension of the geological time of complex geological processes [13].

Geological and geomorphological values can underpin the biodiversity and cultural diversity [14], and the geology elements that dominate in a specific area quite often determine its historical, cultural, and socio-economic development. Usually, in a certain place, the ties between geology and culture are strong [15], which is why the concept of geocultural heritage is proposed [16]. The study of geocultural heritage provides cultural, social, and moral values that concern society in its entirety [17]. Geoheritage includes those elements of geodiversity that have scientific, educational, cultural, aesthetic, and ecological value for humans $[18,19]$.

The cultural values of geodiversity are associated with mythological, historical, archaeological, and spiritual and religious aspects [20,21]. Archaeological value is mainly related to ancient objects or other remnants of an area, and the historical value refers to evidence relating to historical events of humanity associated with geosites [22].

The aesthetic value of a landscape is related to its intrinsic beauty and uniqueness or in the appreciation of its beauty [22]. Intrinsic value is the value within an object itself and it is independent of the evaluation of man [21] because the geodiversity of nature has value in itself, independent of human use (utilitarian value) [23]. According to the literature, the high aesthetic appeal distracts the perception of geological information [24], because landscape is not synonymous with landforms or geological structure [15] and often geological elements are not recognized as the most prevalent. In addition, many times, the historical, cultural, and natural elements of a site are imposed on geological features [25] (p. 457).

The ecological value of geodiversity is understood both in terms of the conservation of geological and geomorphic processes as well as the conservation of biological processes that depend on these natural systems [18].

The intrinsic social and economic value of geoheritage and geodiversity is supported by geoethics [26], which promotes responsible action by adopting social and professional values [27], in order to maintain "a more balanced relationship between humans and nature, considering modern economic and social development expectations" [17].

The economic value that geological or geomorphological features possess [28,29] and the recognition of cultural and aesthetic values of geoheritage [30] are associated with the concept of sustainable geotourism. Respectively, the values of geotourism contribute to the recognition of geoheritage and in the recognition of the values of geoconservation, which concerns protection of the geoheritage [30,31]. Therefore, the goal of geoheritage management structures, other than the development of sustainable geotourism, must be "the geoconservation, protection, and continuous sustainability" [32].

In addressing the challenges of sustainable development, geology, by providing geological information, can contribute to improving decision-making processes [33], because sustainable development is an ethical concept supported by specific values and beliefs. Sustainable development values consist of the prudent use of natural resources and building new economic models that "aim at giving future generations the possibility of discovering other ways to produce energy and using natural resources" [34]. 


\section{The Study Area}

The mountain range of Pelion (1624 m) (Figure 1) is located in eastern Thessaly and extends in a NW-SE direction between the Aegean Sea to the east and the Pagasetic Gulf to the south, creating a natural barrier to the direct communication of the Pagasetic with the North Aegean Sea [35]. Pelion, along with a series of low hills to the south, forms the picturesque peninsula of Magnesia. Its verdant slopes are dominated by the beech forest and formations with poplars and willows, while the maquis reaches the rocky shores [36].

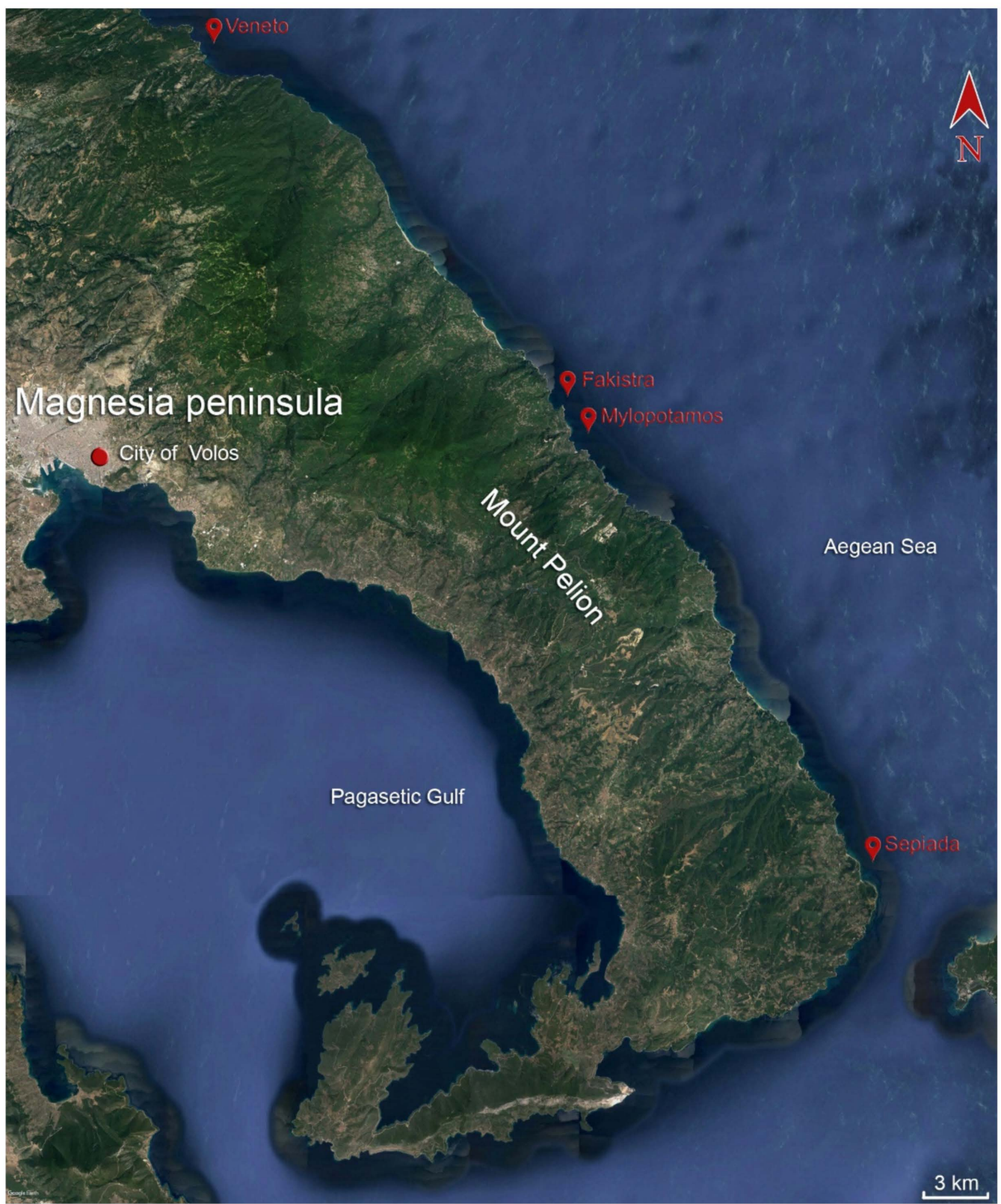

Figure 1. Magnesia peninsula with Mount Pelion area between the Aegean Sea to the East and Pagasetic Gulf to the South.

The intense relief of Pelion is of interest from a depositological, tectonic, and seismological point of view, and many researchers have studied its geomorphology [37-40] (Figure 2). It is composed mainly of alpine and pre-alpine formations [35], and the rocks of the area are mainly slates (phyllites and gneisses), serpentines, and limestones [36]. 
Capes, bays, gulfs, and rocky shores are formed on its shores due to the large rift zones of the area [35]. Coastal processes shape coasts into a variety of impressive coastal landforms, such as coastal caves, sea arches (natural bridges), and sea stacks. These landforms result from the coastal erosion of the rocks and the gradual removal of mainly their soft material [41-46]. Rocky shores and isolated rocks are key habitats of great value for terrestrial and aquatic fauna, rendering their protection very important in cases where humans have already intervened [47].
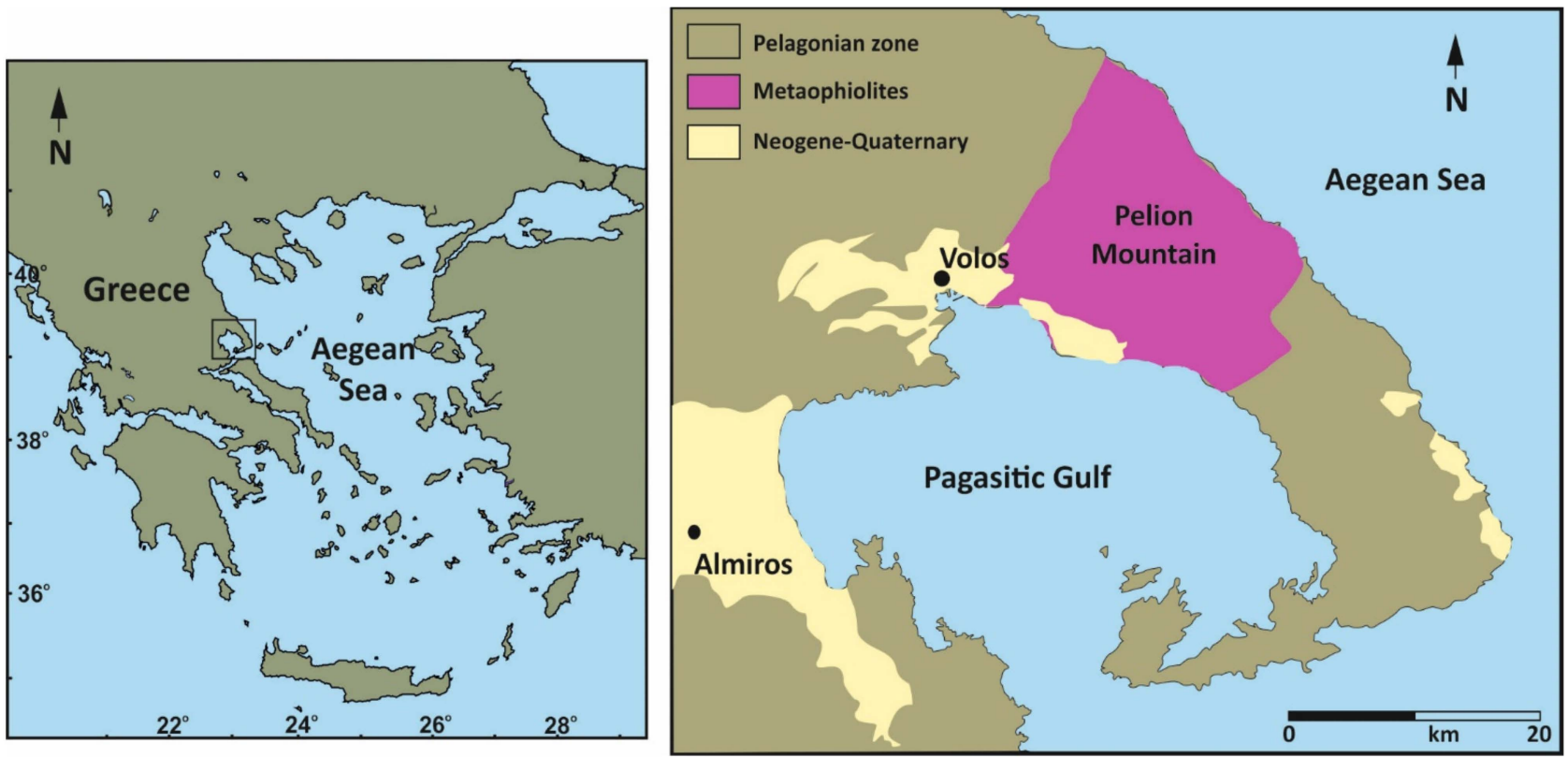

Figure 2. Simplified geological map of Mount Pelion, reprinted from ref. [48] (modified by us).

According to Greek mythology, Pelion was the summer residence of the 12 Gods of Olympus. This is where the Centaurs were born and the legendary Centaur Battle took place. The sea caves of the area are connected with elements of Greek mythology, such as the dominant myth of Thetis and Peleus.

Thetis, a sea deity, lives at the bottom of the sea but is strongly connected to Pelion. In the myth, the sea is her place of origin and the coast of Sepias (Sepias shore) at the SE end of the peninsula of Magnesia is the place that Peleus catches and subdues her [49]. According to the legend, Thetis, in order to avoid the marriage with Peleus, whom Zeus chose as her husband, transformed into a cuttlefish. However, trying to escape from Peleus, she was trapped by him in the sea cave. From the ancient Greek word "sepia" (= cuttlefish), the area was named Sepiada. Tombs of the geometric period have been discovered in the area, as well as scattered architectural elements from Doric columns and a Christian temple with a mosaic floor, on the site of a possible temple of ancient times [50]. In another cave, Thetis transformed into a woman, and after her marriage to Peleus, Achilles was born, the legendary hero of the Trojan War.

At the northeastern tip of Magnesia, on the beach of Veneto, there are also impressive sea caves in the shape of "hipnoi" (=kilns, ovens), in the sea area where most of the Persian fleet was destroyed, according to Herodotus, in $480 \mathrm{BC}$. According to the legend, the wedding of Peleus and Thetis took place in the so-called cave of Aegeas. In Fakistra, in eastern Pelion is the impressive sea cave of Panagia, and near it in the middle of a steep rock is another cave, known as the "secret school", i.e., a school during the Turkish occupation. 


\section{Materials and Method}

\subsection{The Educational Environmental Program}

The educational environmental program entitled "Storm-Tossed Sea Rocks in Pelion Seaside" was designed to be to be implemented both remotely and synchronously due to the COVID-19 pandemic. The main educational goals of the program aim to empower learners with the knowledge, skills, values, and attitudes [5], which are related to the geocultural heritage of the rocky coast landforms of Pelion. Cognition, awareness, attitudes and values, and participation objectives were identified [51]. According to them, the students seek to report basic physical characteristics of rocky coastal landforms, to describe how they were created, to recognize them as places of geological heritage [52] and as ecosystems, and to understand and realize the values of geodiversity and geoheritage, in order to develop a moral code of conduct and a sense of responsibility for the protection and preservation of the geoenvironment.

It is aimed at third-grade junior high school (gymnasium) students and fully incorporates children with mobility and special learning problems. Its duration corresponds to a complete annual program of environmental education in secondary education, i.e., it corresponds to twenty-two-hour educational meetings (episodes). In an environment fully supported by ICT, teaching methods and techniques are implemented in the framework of constructivist theory. The whole educational process is based on the storyline methodology [53] and educational techniques are used, such as cooperative learning [54,55], discovery learning and situated learning [56], such as the experiential workshop, role play (the role-playing method), brainstorming, ethical dilemmas, the action research method, case study, discussion [57], and the organization of speech based on the use of arguments (debate).

Using new technologies, students overcame obstacles, such as traffic bans during the COVID-19 pandemic, and digitally visited the "storm-tossed" sea rocks (with the assistance of local government officials) via drone. They searched the internet for information and discussed and disseminated information as well as digital media about the origin and physical characteristics of the sea rocks. They interviewed top local government executives (in the fields of culture and economics) and a diver from the Institute of Marine Archaeological Research to discover the values of the geoheritage [3] that are intertwined with the rocky coast landforms. They watched videos about the marine life and the birds that nest in the sea rocks, and through a digital theatrical event, they developed perceptions of respect and responsible behavior regarding the geological heritage. Through works, presentations, and public discussions, they developed and disseminated geoethics attitudes and values of sustainability.

A significant feature of the scenario is the inclusion of interdisciplinary and multidisciplinary approaches, in order to holistically examine and investigate the issue, so that it can be part of the fields of STEM and HASS [3,58,59].

What makes the digital scenario of PSD unique and innovative, is its realization through fully remote synchronous online education processes using new technologies and ICTs [60]. Typical innovative actions are the students' digital visits (via drone), the digital theatrical event (via Webex), the digital face-to-face interviews (via Webex) and the general organization and asynchronous educational management (via e-me). The educational methodology implementation platform can also be characterized as an innovation, i.e., the methodology of the storyline [53]. In summary, the thematic units of the program are the following: (1) Introduction to the sea rocks, entitled: "I know the Sea Rocks"; (2) Identification of the geoenvironmental values and parameters of the geoheritage, entitled: "The value of the Sea Rocks of Pelion"; (3) Development of perceptions of geoethics and values of sustainability, entitled: "The Rocks make me aware"; (4) Development and dissemination of concepts of ecology, environmental protection, and sustainability, entitled: "I, the Rocks the environment and the future". 


\subsection{Evaluation of the Program}

The evaluation of the program was carried out based on the branch of student empowerment. The knowledge and skills branches were evaluated by utilizing the Rubric technique, which was designed and completed by the students themselves. The attitudes branch was evaluated by using a questionnaire on the parents, teachers, and education and state officials to whom the results were presented. The teachers of the program faced a challenge in the evaluation of the program regarding the success of the students' empowerment goals in the values of geoheritage. Finally, the branch of values, i.e., the evaluation of the empowerment of students in geoheritage values, which emerged in this educational program and were related to the geodiversity of the rocky coast landforms of Pelion, was carried out based on the examination of interviews of the students themselves. Essentially, a qualitative research strategy was followed based on the technique of thematic analysis. The technique was selected as most appropriate for "mining" conceptual patterns, the analysis of which would inform the teachers, in a valid, reliable, and simultaneously convenient and quick way, that the perceptions of geoheritage values were disseminated to the students through the program. Thus, we pursued the conduct of a small number of interviews with students, which were based on an equally small number of targeted questions, in order to compile a proposition for the evaluation of values teaching in the educational community, which could be implemented even on a daily basis, when the teacher attempts to disseminate and empower their students on values. Unquestionably, the said evaluative procedure does not aim at a generalization of results in larger groups of students. The methodology, results, and conclusions from the evaluation of the geocultural values encouragement are presented in this survey.

\section{Research Question}

In the present survey, the concept of value empowerment, as mentioned in the concept of UNESCO for Education for Sustainable Development (1, para. 2) [5], is considered the perceptual empowerment of students in the values of geocultural heritage. Furthermore, it is considered that "... perception is fundamentally a matter of employing perceptual capacities whose natural function is to discriminate and single out particulars in our environment." [61] (p. 75).

An attempt was made to examine the empowerment of students concerning five (5) values which are consistent with the geoheritage values of pupils and students surveyed by Georgousis et al. [3] and the following survey question (SQ) was asked:

SQ: The implementation of the environmental program "Storm-Tossed Sea Rocks in Pelion Seaside", achieved the empowerment of students in geoheritage values, geological values, aesthetic values, cultural values, ecological values of geodiversity, and sustainable development values.

\subsection{Methods}

As mentioned above (3.2, para. 1), the training program was evaluated (class evaluation) with "standard" educational methods of quantitative strategy, such as the rubric, and the questionnaire which was based on answers to Likert-type scales. This typical evaluation is the subject of other studies by the authors and not the present one. However, the authors sought to estimate separately whether the processes of the educational program succeeded in spreading the values of geocultural heritage to the students, with their subsequent empowerment in these values as described in the UNESCO concept for empowerment in education for sustainable development (1, para. 2). 
The authors did not apply quantitative methods or content analysis methods. The quality strategy was chosen based on the methodology of thematic analysis because it "... allows the researcher to see and make sense of collective or shared meanings and experiences. [and because it] ... is a way of identifying what is common to the way a topic is talked ... about and of making sense of those commonalities" [62] (p. 57). This is essentially what the authors were interested in, in addition to the usual "typical" educational evaluation of the program.

A reliable research approach of semantic (qualitative) rather than quantitative character was sought because the authors' interest is focused on answering the research question on whether the program enabled the empowerment of students' perceptions by diffusing the values of geocultural heritage, and not to elaborate on the degree of influence, the number of students influenced, or a similar question of measurable tone. Thus, the emphasis was placed on identifying semantic motifs that would serve as confirmation that the program influenced students' perceptions of geocultural heritage values.

The reflexive approaches of thematic analysis were followed, after the development of categories with themes developed by codes, which in turn were identified as common semantic patterns with implicit or latent meaning around the centrally organized meanings of sensitive concepts concerning geocultural heritage values [63] (p. 39). In this way, five categories of values were developed which concerned geocultural heritage values and one category (emotional arousal), which was not examined in the present work.

A method should also be chosen that would lead to the answer to the research question easily, practically, and reliably, since it was a "routine task" for teachers. The technique of thematic analysis allows a small or very small sample of participants. Braun and Clarke (2016) state that the logic of sampling, in thematic analysis, challenges the claim that larger samples are better and goes so far as to challenge even the very idea of "sampling" itself [64] (p. 741). In addition, Fugard and Potts (2015) suggest that the sample size can range from two interviewees up to four hundred [65] (p. 669). Indeed, the examination of five out of twenty-five students in the class, based on only four questions, produced semantic patterns of eighteen codes and six categories, which allowed the authors to conclude that the program influenced the diffusion of geocultural heritage values and to associatively conclude that students were empowered in these values. The latter can defend the selection and implementation of a research process that yielded results easily and practically and is therefore recommended by the authors to be considered in similar cases of result evaluation in the "daily" educational process of developing complex semantic issues, such as empowerment in values.

More specifically, a survey was conducted based on the qualitative strategy [66], cross-sectional research design [66] (p. 58), and the technique of thematic analysis [67]. The aforementioned research combination was carried out to enable the identification of semantic motifs and specific combinations of correlations, which would help answer the survey question asked.

The semi-structured interview was used as a research tool for data collection [68]. A structured interview diagram of four (4) questions was prepared. The questions were worded in such a way as to enable students to refer to verbal patterns about whether they had been empowered in specific values but without biasing them or directing them to specific answers. The teachers of the program listened to and recorded the answers of the students. It is noted that students were encouraged to refer to verbal patterns that reflected the values of geoheritage as outcomes of their experiences, and, as much as possible, solely from their participation in the program.

As a sample, five (5) students were randomly selected (from the 22 participants in the environmental education program) with the purposeful random sampling methodology in order to increase the reliability of the survey [67] (p. 83). Students with serial class numbers $2,6,10,14,18$ were selected. 
The five concepts of the values under consideration were identified as sensitizing concepts: (1) geological value, (2) aesthetic value, (3) cultural value, (4) ecological value and (5) sustainable development value:

Geological value. Geological value is defined as the value of natural sites with geological and physiographical formations which are characterized by outstanding universal value from the aesthetic point of view, from the point of view of science, conservation, or natural beauty [69] (p. 20, [70]).

Aesthetic value. The aesthetic value of a geomorphic structure lies in the richness of the perceptual and emotional experiences offered by its aesthetic characteristics and properties, and in the way these perceptual and emotional experiences are constructed and correlated with each other [71].

Cultural value. Cultural values are those cultural elements that modern Greek society accepts, shares, considers as part of its culture, values culturally and attaches value to. These elements include mythological, historical, and archaeological elements in relation to characteristics that could be considered as part of nature [72] (p. 129).

Ecological value. Regarding ecological value, the definition of Cordell, Murphy, Riitters, and Harvard (2005) is adopted: "We define ecological value generally as the level of benefits that space, water, minerals, biota, and all other factors that make up natural ecosystems provide to support native life forms" [73] (p. 206).

Sustainability value. Sustainability values are those values that promote attitudes and behaviors aimed at the reconciliation and strengthening of the links between economic development and environmental conservation, through the sustainable use of natural resources and the protection of the environment, the basic ecological processes, the support of life, and animal diversity [8,74].

The semi-structured interview consisted of the following four (4) questions:

Q1. In the program, we saw images and live videos from sea rocks of Pelion. What impressed you about their presence when you first noticed them?

Q2. We dealt with the mechanisms of creating sea rocks. Tell us, what impressed you most about the creation of sea rocks?

Q3. Were our ancestors, the ancient Greeks, aware of the peculiarity of the geomorphology of the sea rocks? On what evidence do you base your answer?

Q4. State (based on your personal opinion) the three most adverse effects that the pollution of a storm-tossed sea rock can have from the coarse oil of a marine oil slick.

According to Bryman, the issue of validity does not seem to affect much a qualitative strategy study [66] (p. 389). However, in this survey, we are interested in examining both validity and reliability. Thus, we can ensure an increased ecological (environmental) validity since the words of the students are verbal patterns of conditions, attitudes, and values, which emerged from their experiential actions in the environmental program and which have already been implemented, are being implemented and have been disseminated by them in their natural social environment (at school, in the family, in society). In addition, we can ensure the increased internal validity of the survey since the impartial (bias) syntax of the questions and the codified examination of the semantic patterns of the answers within the sensitizing concepts advocate the stability of the conclusions and causal relationships that were identified [66]. We can also ensure high descriptive validity since the recording techniques and the processing technique (thematic analysis) enhance the accurate and valid examination of the verbal motifs of the interviewees [75] (pp. 285-286). We can ensure increased interpretive validity since the words of the interviewed students present their perspective on the subject and by definition, include knowledge and concepts, beliefs and influences, and evaluations and judgments on it [75] (pp. 288-289). Furthermore, we can ensure increased theoretical validity since the levels of thematic analysis (codes and categories) were based on sensitizing concepts and secondarily on definitive concepts which emerged from a theoretical review [75] (pp. 291-292). Finally, efforts are made to 
develop the reliability of the research, both through the application of purposeful random sampling and through the careful formulation of questions (unbiased syntax).

As a methodological framework in data analysis, as mentioned above, the technique of thematic analysis is followed [62]. One theme and five categories are recorded which correspond to each of the five sensitizing concepts.

The interviews were recorded; the answers were distributed per question and examined semantically. The concept patterns were identified, which were marked in different colors based on category and distributed in codes. This results in fourteen codes, which are grouped into the five theoretically identified categories. It is noted that the codes "geoconservation value perception" and "geoethical perception" refer to two categories: "geological value empowerment" and "sustainable development values empowerment".

It is noted that during the implementation of the thematic analysis procedures, meanings were identified which were classified into two new codes (hedonic feelings and negative emotions). The new codes were included in a new category-emotional arousalthe markings and recordings were made but these did not concern the present survey and the careful examination of their effect on education in geocultural values is proposed as the subject of a new research.

The theme, categories, codes, and color marks are presented in Table 1.

Using a simple copywriter, the answers were grouped and the meanings were marked and recorded by their inclusion in the respective codes. Figure 3 shows the procedure for the fourth question $(\mathrm{Q} 4)$.

Table 1. Thematic analysis: theme, categories, codes, color marking index.

\begin{tabular}{|c|c|c|}
\hline Codes $(16+2)^{a}$ & Categories $(5+1)^{b}$ & Theme (1) \\
\hline Geological knowledge & & \multirow{16}{*}{$\begin{array}{l}\text { Geocultural heritage } \\
\text { Empowerment }\end{array}$} \\
\hline Geological time perception & & \\
\hline Geomorphic structures perception & & \\
\hline Geoconservation value perception & & \\
\hline Geoethical perception & & \\
\hline Aesthetic qualities & $\begin{array}{l}\text { Aesthetic value } \\
\text { empowerment }\end{array}$ & \\
\hline Mythological correlation & & \\
\hline Historical correlation & & \\
\hline Archaeological correlation & & \\
\hline Biological processes perception & \multirow[t]{2}{*}{ Ecological value } & \\
\hline Intrinsic value perception & & \\
\hline Economic value perception & & \\
\hline Social value perception & & \\
\hline Geotouristic value perception & & \\
\hline Geoconservation value perception & & \\
\hline Geoethical perception & & \\
\hline Hedonic feelings & \multirow[t]{2}{*}{ Emotional arousal } & \\
\hline Negative emotions & & \\
\hline
\end{tabular}


Q4 State (based on your personal opinion) the three most adverse effects that the pollution of a storm-tossed sea rock can have from the coarse oil of a marine oil slick.

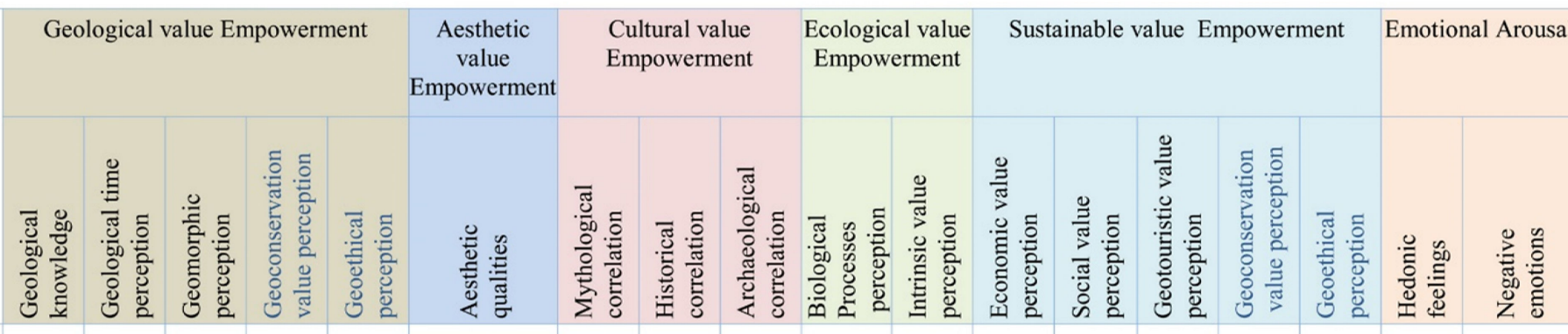

S1. It drives me crazy to think that a crime like this [meaning the oil spill], will destroy in one moment the sculptural expression of nature, that has lasted millions of years, will eliminate thousands of innocent lives [he means sea life], and everywhere will be just desolate.

52. Sea life will just disappear, fishermen will starve, hotel owners as well, villages will be abandoned. I just feel sorry for my classmates... [nodding in disappointment].

S3. What can I say? That birds will disappear, fish, sea plants and all other animals? That those giants will be in sanely dirty? That we will all be ashamed of them? [he means the people responsible for the pollution and looks disheartened].

S4. We will not be able to admire them. We will not be able to say that this here is the place where Achille's mother was born. We will not be able to swim with the Spari. [fish species from the Aegean sea: Sparus (Diplodus annularis)].

55. Fish and birds will die, shops will close, we will not be able to go on holidays there, everything will be completely destroyed.

$$
\text { Num of conceptual pattorns per Code: }
$$

Figure 3. Concept patterns marking and recording, and inclusion in the respective codes (question Q4). 


\section{Results and Discussion}

Through the identification and recording of conceptual patterns, in the sample students' answers to the four questions of the interview, $16(+2)$ codes were recognized, which, in turn, were developed or combined into six categories, five of which correspond to the sensitizing concepts of the present survey. As a consequence, we can suggest that the selection of the random sample of five students (among the 22 students of the class) provided valid results and a clear conceptualization of what conceptual patterns represent [64] (p. 742).

The results are presented and discussed in the context of the categories identified.

Category 1: geological value empowerment. Conceptual patterns were identified which can be considered as part of the five codes of geological value empowerment and, in fact, in the answers of all students.

To illustrate, answers to question 2 are quoted below:

Q2-S2. "I never thought that the power of water and air could create such beautiful formations". Here, we find that the student presents concepts which show both their empowerment in geological knowledge and geomorphic structure perception.

Q2-S4. "I thought the sea rocks were cut off from big rocks and rolled on the beach and now I learned that they were created by the erosion of the waves for thousands of years". What we can identify in the words of the student is a geological time perception which did not even exist before the implementation of the environmental program.

Q2-S5. "I could not imagine that in the place of the arch of Mylopotamos, after thousands of years, there would be a separate sea stack, and on the adjacent beach the cliff could be transformed into an arch". Here, we pinpoint concepts that refer to three codes (geological knowledge, geological time perception, geomorphic structures perception).

Patterns are also mentioned in answers to other questions such as question 4 . For example, an answer is given:

Q4-S1: "It drives me crazy to think that a crime like this [meaning the oil spill], will destroy in one moment the sculptural expression of nature that has lasted millions of years, it will eliminate thousands of innocent lives [he means sea life], and the whole place will be just desolate". In this expression, we find semantic patterns that indicate the strengthening of geoconservation value perception and geoethical perception in the student. Of course, we find also concepts of geological time perception as well as geological knowledge. What is more, we encounter expression of negative emotions that confirm the development of life value [6] (p. 2). In conclusion, based on the results of the research within the category 1-geological value empowerment, we find that students developed the geological value after showing that they acquired geological knowledge, realized geological time, recognized elements of geomorphological formations (sea arches, sea caves, sea stacks), and acquired the ability to identify and describe different types of reliefs, the ability to identify natural factors that help the processes of change of the coastal environment (tectonic action, wind, sea level change, mainly wave action), and the mechanisms of retreat of coastal cliffs. They also realized the effects of pollution, the need for protection where humans intervene, and the need for rational management with the goal of geoconservation. Eventually, what can be inferred is that the educational program contributed to the dissemination of recognition of the relational value of geoformations; consequently, it disseminated the moral basis for the support of the "in situ" conservation of these geological goods, which even lack a commercial value [76].

Category 2: aesthetic value empowerment. Conceptual patterns are observed which confirm the empowerment of students in aesthetic value. Answers such as:

Q1-S1: "The beauty, of course, [looks ecstatic] by the sea, the rocks make the beaches look more than unique. They are simply insurmountable".

Q1-S3: "The majesty of the rocks. The various strange shapes that remind me of a sci-fi movie set on exoplanets [looks fascinated]. They are wonders of nature". 
We find patterns of characteristic youthful aesthetics that support the claim that students have been empowered in aesthetic value. It seems that students recognize the high aesthetic value of isolated rocks, sea arches, and sea caves, perceive rocky coast landforms as natural wonders or mysterious locations, and imply the reasons that these areas attract nature lovers, geologists, walkers, etc. In addition, semantic patterns were identified (such as "various weird shapes" in student's answer 53), which refer to an "... aesthetics-based classification of geological structures in outcrops should be based on the view of patterns produced by these structures and perceived by visitors" [77] (p. 47), which can enrich the subject matter of similar educational programs in the future, since it appears that the acquisition of an extensive aesthetic vocabulary is positively correlated with the development of understanding skills [78]. Therefore, this will contribute positively to the dissemination of the aesthetic value of geoheritage geoformations to the students.

Category 3: cultural value empowerment. Conceptual patterns were identified that suggest that the students correlated mythological, historical, and archaeological concepts with rocky coast landforms. This means that the students were empowered in cultural value. Essentially, the conceptual patterns were identified in the answers to question Q3. The answers are characteristically mentioned:

Q3-S1. "Of course, they were aware of this miracle. This is evident from the fact that the ancient Greeks associated these places with mythical deities. Didn't they do that in every special place?"

Q3-S5. "They had, and we did not have [Shows coyness]. I could not imagine that in the place where our father takes us swim, Achilles' mother was trapped [She looks impressed]".

Therefore, we find that the students better understood the relationship between natural and cultural environment. They acquired the ability to recognize elements of geomorphological formations associated with cultural elements and historical, archaeological, and mythological aspects. They acquired knowledge about the connection of geological knowledge with mythological elements of the place (sea deities, Thetis, Peleus, Poseidon, Achilles) and historical elements (sinking of a Persian fleet at the cape of Sepiada). Thus, we can argue that the students were initially empowered in the cultural value of rocky coastal landforms. Indeed, student S1 seems to be affected by his contact with the geoformations and this is obvious in the phrases "Of course they were aware" and "special place", which make it apparent that he realizes the deeper cultural value, as he expresses his certainty that the place is culturally special. However, student S5 (on the basis of his answer above) does not seem to be considerably influenced by the cultural product which accompanies the geoformation, since he only wondered about his own ignorance. That is, it seems that the sample students correlated Greek culture and history elements with the marine geoformations of Pelion superficially (solely as facts), but few semantic patterns show a deeper realization of their cultural value. The teachers expected a wider spirituality in the answers because they expected that, through this educational program, the unique values and value orientations inherent in the Greek civilization influence the students' worldview and attitude towards life [79]. Thus, the educational program is considered to have failed to provide the possibility of cultural value development to the students at a desirable level. Maybe, as far as cultural value empowerment is concerned, the program could implement different teaching techniques, such as problem-based learning (PBL), as it was put in use by Curto, Barreca, Coscia, Ferrando, Fregonara, and Rolando (2021) in an educational program, aimed at the improvement of cultural value in architecture and planning schools [80]. This will be pursued in future educational programs of the sort.

Category 4: ecological value empowerment. Two codes, conceptual patterns "biological processes perception" and "intrinsic value perception", were identified in this category. Answers to question 4 (case of marine oil spill pollution) are given:

Q4-S3. "What can I say? That birds will disappear, fish, sea plants and all other animals? That those giants will be insanely dirty? That we will all be ashamed of them? [he means the people responsible for the pollution and looks disheartened]". 
Q4-S4. "We will not be able to admire them. We will not be able to say that this here is the place where Achilles' mother was born. We will not be able to swim with the Spari. [fish species from the Aegean Sea: Sparus (Diplodus annularis)]".

We find conceptual patterns that show empowerment in a significant number of values, some of which are biological processes perception ("birds, fish, marine plants and other animals will disappear", "we will not be able to swim with the Spari"). We also find intrinsic value perception conceptual patterns such as "The sea rocks have value on their own", "Those giants", and "We will not be able to admire them". Thus, we find that the students realized that geomorphological formations are at the same time habitats of great value for invertebrates, marine plants, fish, and marine life in general, but are also in themselves environmental elements of high intrinsic value. Additionally, it is remarkable that ecological value perception was disseminated accordingly with students' aesthetic value, since correlation semantic patterns have been identified, which refer to ecological issues and simultaneously to issues of scenic enjoyment and outdoor recreation as recreational activities such as bird and fish watching, swimming, rock climbing, and nature and submarine photography [81] (p. 18).

Category 5: sustainable development values empowerment. In the category of sustainable development values empowerment, conceptual patterns were identified for five codes: the economic value perception, the social value perception, the geotouristic value perception, the geoconservation value perception, and the geoethical perception (the latter two also affect the category geological value empowerment). Category examination seems to correspond to conceptual patterns on the basis of the answers to various questions but are mainly found in the answers to question 4 (possible contamination of geomorphological elements):

Q4-S2. "Sea life will just disappear, fishermen will starve, hotel owners as well, villages will be abandoned. I just feel sorry for my classmates ... [nodding in disappointment]". Here, we observe conceptual patterns that feature economic value perception by the student ("Fishermen and hoteliers will be hungry"), as well as social value perception and geotouristic value perception ("Hoteliers will be hungry").

Q4-S5. "Fish and birds will die, shops will close, we will not be able to go on holidays there, everything will be completely destroyed". Here, too, we observe patterns that show the development of economic, social, and geotouristic values perception.

In addition, it is noteworthy that patterns of geoethical perception were identified, such as "I feel sorry for my classmates" and "the place is gone". Conceptual patterns of geoconservation value perception were also identified. A typical answer to question 2 (about the creation of rocky coast landforms) is:

Q2-S3. "I was impressed that nature does this with millions of years of work to make us all happy. You [the teachers], us, our children and our children's children".

Above, we can pinpoint expressions or beliefs about the value of geoformations and their properties, wherein students use terms which convey meanings of good or bad or desirable content ("I was impressed that nature does that through millions of years work so that we can all enjoy it") or undesirable content "I am sorry for my classmates", which leads us to identify sustainable development values in their words [82] (p. 7). We also identify semantic patterns in which they are not considered " ... as part of a broader socially constructed view of 'progress', but as part of an essentially non-human logic, located in biological systems" [83] (p. 7), which means that conceptions of sustainable development values are present. To illustrate this, the words of student S3 are quoted "That those giants will be insanely dirty? That we will all be ashamed of them?", with which he marginalizes human logic by defending non-human logic (of giant geoformation value). Lastly, we can identify semantic patterns that imply economic growth (crucial in order to fight poverty) in combination with environmental quality protection (circular economy) [84] (p. 1441). Student S2 illustrates this with his phrase "Sea life will just disappear, fishermen will starve..." 
Based on the above, it seems that we can argue that the environmental program has succeeded in strengthening the sustainable development values of the participating students via the dissemination of these values.

We observe frequent coexistence of conceptual patterns from various codes and categories. As aforementioned, a correlation was marked between the ecological value category and the aesthetic value one (the case of marine oil spill pollution), perhaps because students were asked to report three adverse effects in the event of a disaster, thus highlighting the diverse effects, all underlined by these common values, that were most strongly impressed on them. Specifically for the value of sustainability, codes were identified that are consistent with other values, especially that of geological value. The answer below is characteristic:

Q4-S1: "It drives me crazy to think that a crime like this [meaning the oil spill], will destroy in one moment the sculptural expression of nature that has lasted millions of years, it will eliminate thousands of innocent lives [he means sea life], and the whole place will be just desolate". In it we find codes from all categories, a common finding in all the answers of all the participating students but to a lesser degree. The latter leads us to assume that geocultural heritage values coexist more or less in individuals who have received educational empowerment, even in some of them. However, new research can confirm that.

Based on the individual evaluations of the educational branches of the program and mainly the aforementioned approach of evaluating the empowerment of students in geoethical values, we can support the following: the design of the program envisaged a synchronous online learning environment which [although seemingly underestimated by many teachers] proved to offer multiple opportunities for a variety of activities which enhanced learners' participation, helped build new knowledge and, above all, strengthened values in students, which are in line with those suggested by Doukakis, Alexopoulos, and Niari [60] (p. 174).

We also find the expression of positive (hedonic) feelings or negative emotions in many students' responses either as verbal patterns or as semantic expressions ("hedonic feelings" in Gkargkavouzi, Halkos, and Matsiori) [85], ("negative emotions" in Clayton and Karazsia) [86]. Firstly, this explains the significant performance in the cognitive objectives of the program (the results of this evaluation are not presented here), which confirms the claims of Doukakis, Alexopoulos, and Niari (2021) [60] that the educational environment that promotes emotional experiences contributes to learning [60] (p. 179). The same leads us to wonder whether the empowerment of geocultural heritage values affects the emotions of individuals. However, this is also the subject of a new study.

Theme 1: Geocultural Heritage Empowerment.

The aforementioned results in the five categories compose the unique theme of thematic analysis (geocultural heritage empowerment). Thus, we can support the view that the educational environmental program achieved the dissemination of the geoheritage values under examination, allowing for a lack in the dissemination of the cultural value. In addition, what was identified was the development of feelings whose origins could be connected with the said dissemination of values, that is, with the achievement of the educational and pedagogical aims of the program.

The latter point leads us to a positive answer to the survey question (SQ) posed; we can, in other words, support the view that the implementation of the environmental program "Storm-Tossed Sea Rocks in Pelion Seaside", achieved the perceptual empowerment of students in geoheritage values, geological value, aesthetic value, cultural value, ecological value of geodiversity and sustainable development values, as these are examined by Georgousis, Savelides, Mosios, Holokolos, and Drinia [3].

Additionally, the importance of supporting the educational program with ICT has been underlined, since it would be absolutely impossible for the students to approach these geoformations "live", within the forced distance learning circumstances. This further highlights the need for constant updates of the technical part of similar programs in the 
future, via the implementation of new visual approach techniques of cultural heritage (visual media/visualization tools), which are recommended by researchers (e.g., Scopigno 2021) [87].

As mentioned before, the findings appear to advocate that by means of the educational program, values of geoheritage were disseminated to the students; that is, Vygotsky's scaffolding for the empowerment of students in the values of geoheritage was "built", in a sense. The fact that conclusions were drawn which could mark the educational procedure as effective, or the fact that a modification is required, partly or as a whole, seem to provide the authors with the ease to recommend the qualitative technique of thematic analysis as an evaluation procedure for educational programs, syllabi, or curricula, especially if the dissemination or students' perceptual empowerment in values are to be evaluated.

\section{Conclusions}

An environmental education program was designed and implemented with the theme and main goal of empowering students in the values of geoheritage. In the present survey, the concept of empowerment is considered as the perceptual empowerment of students in the geocultural heritage values.

There were concerns among teachers about how to control the achievement of the goal in terms of empowering students in the values of geoheritage. The researchers chose to apply qualitative research techniques, with the main technique being thematic analysis. The research question was identified as to whether the implementation of the environmental program "Storm-Tossed Sea Rocks in Pelion Seaside", achieved the empowerment of students in geocultural values, geological, aesthetic, cultural, ecological, and sustainable development.

In order to answer this question, four-question interviews were conducted with five randomly selected students who participated in the program. The data were examined, and conceptual patterns were identified which were included in eighteen codes. The codes were divided into five categories, the analysis of which led to the answer to the research question.

Thus, firstly, it seems that we can argue that the implementation of the environmental program achieved the empowerment (as the perceptual empowerment) of students in geocultural values. In addition, it was shown that the students' perceptions were strengthened in topics and values of geocultural heritage and sustainability, such as geological knowledge, geological time perception, geomorphic structures perception, geoconservation value perception, geoethical perception, aesthetic qualities perception, mythological, historical, and archaeological aspects correlated with geology, biological processes perception, intrinsic value perception, economic value perception, social value perception, geotouristic value perception, geoconservation value perception, and geoethical attitudes perception. Students were also shown to develop feelings of environmental sensitivity, which suggests further investigation.

It follows from the above that the educational approach with a focus on empowering the students in geocultural heritage issues was cognitively, pedagogically, and emotionally beneficial. This leads to the support of the confirmation of the research conclusions of Georgousis, Savelides, Mosios, Holokolos, and Drinia on "The Need for Geoethical Awareness: The Importance of Geoenvironmental Education in Geoheritage Understanding in the Case of Meteora Geomorphes, Greece" [3]. That is, there is a need to enrich the curricula of environmental education/education for the environment and sustainability with issues of biogeomorphology, geodiversity, and geocultural heritage, which will contribute to geoheritage understanding and geoethical awareness.

The authors of the present survey recommend the qualitative technique of thematic analysis as an evaluation procedure of educational programs aiming at the dissemination or empowerment of values. 
Author Contributions: Conceptualization, E.G., M.S., S.S. and H.D.; Data curation, E.G. and M.-V.H.; Formal analysis, M.S.; Investigation, E.G. and S.S.; Methodology, E.G., M.S., S.S. and H.D.; Resources, E.G., M.S., S.S. and M.-V.H.; Writing-original draft, E.G., M.S., S.S., M.-V.H. and H.D.; Writingreview \& editing, E.G., M.S., M.-V.H. and H.D.; Supervision, S.S. and H.D. All authors have read and agreed to the published version of the manuscript.

Funding: This research received no external funding.

Institutional Review Board Statement: Not applicable.

Informed Consent Statement: Not applicable.

Data Availability Statement: The data presented in this study are available on request from the corresponding author.

Acknowledgments: The authors gratefully thank the journal academic editor and the three reviewers for their thorough consideration of this paper.

Conflicts of Interest: The authors declare no conflict of interest.

\section{References}

1. UNECE. Greece: Implementation of the UNECE Strategy for Education for Sustainable Development (2017-2019). Greece Report 2017-2019. Available online: https://unece.org/DAM/env/esd/Implementation/NIR_2018/Preface_final_GR.pdf (accessed on 15 June 2021).

2. Trikolas, K.; Ladas, I. The necessity of teaching earth sciences in secondary education. In Proceedings of the 3rd International GEOschools Conference, Teaching Geosciences in Europe from Primary to Secondary School, Athens, Greece, 28-29 September 2013; pp. 73-76. (In Greek).

3. Georgousis, E.; Savelides, S.; Mosios, S.; Holokolos, M.-V.; Drinia, H. The Need for Geoethical Awareness: The Importance of Geoenvironmental Education in Geoheritage Understanding in the Case of Meteora Geomorphes, Greece. Sustainability 2021, 13, 6626. [CrossRef]

4. Maran, A. Geoconservation in Serbia-State of Play and Future Perspectives. Eur. Geol. 2012, 34, 1-72. Available online: http:/ / eurogeologists.eu/wp-content/uploads/2015/09/a_Magazine-Dec2012.pdf\#page=29 (accessed on 15 June 2021).

5. UNESCO. Education for Sustainable Development. Available online: https://en.unesco.org/themes/education-sustainabledevelopment (accessed on 9 August 2021).

6. Steg, L.; de Groot, J.I.M. Environmental values. In The Oxford Handbook of Environmental and Conservation Psychology; Clayton, S., Ed.; Oxford University Press: New York, NY, USA, 2012; pp. 81-92. [CrossRef]

7. Chuanhui, Z.; Hanwei, Z. Cultivation of environmental values for university students under strategic background of environmental informationization. Energy Proc. 2011, 5, 945-951. [CrossRef]

8. Tilbury, D. Environmental Education for Sustainability: Defining the new focus of environmental education in the 1990s. Environ. Educ. Res. 1995, 1, 195-212. [CrossRef]

9. Carreras, J.; Druguet, E. Geological heritage, an essential part of the integral management of World heritage in protected sites. In Geological Heritage and Its Conservation and Management, Proceedings of the Third International Symposium Pro Geo on the Conservation of the Geological Heritage, Madrid, Spain, 23-25 November 1999; Barretino, D., Wimbledon, W.A.P., Gallego, E., Eds.; Geological and Mining Institute: Madrid, Spain, 2000; pp. 95-110.

10. Mata-Perelló, J.M.; Mata-Leonart, R.; Vintró-Sánchez, C. A New Classification of Geological Resources. Dyna 2011, 78, 243-249. Available online: https:/ / www.redalyc.org/pdf/496/49621159029.pdf (accessed on 23 April 2020).

11. Dodick, J.; Orion, N. Measuring student understanding of geological time. Sci. Educ. 2003, 87, 708-731. [CrossRef]

12. Cervato, C.; Frodeman, R. The Significance of Geologic Time: Cultural, Educational, and Economic Frameworks. Special Paper Geol. Soc. Am. 2012, 486, 19-27. [CrossRef]

13. Gómez-Gonçalves, A.; Corrochano, D.; Fuertes-Prieto, M.Á.; Ballegeer, A.-M. How Long Has It Taken for the Physical Landscape to Form? Conceptions of Spanish Pre-Service Teachers. Educ. Sci. 2020, 10, 373. [CrossRef]

14. Dingwall, P.R.; Weighell, T.; Badman, T. Geological World Heritage: A Global Framework: A Contribution to the Global Theme Study of World Heritage Natural Sites; IUCN: Gland, Switzerland, 2005. Available online: https://portals.iucn.org/library/sites/library/ files/documents/Rep-2005-009.pdf (accessed on 10 June 2021).

15. Reynard, E.; Giusti, C. The landscape and the cultural value of geoheritage. In Geoheritage: Assessment, Protection, and Management; Reynard, E., Brilha, J., Eds.; Elsevier: Amsterdam, The Netherlands, 2018; pp. 147-165. [CrossRef]

16. Scarlett, J.P.; Riede, F. The Dark Geocultural Heritage of Volcanoes: Combining Cultural and Geoheritage Perspectives for Mutual Benefit. Geoheritage 2019, 11, 1705-1721. [CrossRef]

17. Bobrowsky, P.; Cronin, V.S.; Di Capua, G.; Kieffer, S.W.; Peppoloni, S. The emerging field of geoethics. In Scientific Integrity and Ethics in the Geosciences; Wiley: Hoboken, NJ, USA, 2017; pp. 175-212. [CrossRef]

18. Sharples, C. Concepts and Principles of Geoconservation; Tasmanian Parks and Wildlife Service: Hobart, TAS, Australia, 2002. Available online: http:/ / www.dpipwe.tas.gov.au/Documents / geoconservation.pdf (accessed on 10 July 2021). 
19. Woo, K.S. Role of IUCN WCPA Geoheritage Specialist Group for geoheritage conservation and recognition of World Heritage Sites, Global Geoparks and other protected areas. In Proceedings of the 19th EGU General Assembly, Vienna, Austria, $23-28$ April 2017.

20. Gray, M. Geodiversity: Valuing and Conserving Abiotic Nature; John Wiley: Chichester, UK, 2004. Available online: https://geoduma. files.wordpress.com/2010/02/geodiversity.pdf (accessed on 12 July 2021).

21. Kubalíková, L. Geomorphosite assessment for geotourism purposes. Czech. J. Tour. 2013, 2, 80-104. [CrossRef]

22. Magagna, A.; Ferrero, E.; Giardino, M.; Lozar, F.; Perotti, L. A Selection of Geological Tours for Promoting the Italian Geological Heritage in the Secondary Schools. Geoheritage 2013, 5, 265-273. [CrossRef]

23. Nikitina, N.K. Geoethics: Theory, Principles, Problems, 2nd ed.; Geoinformmark, Ltd.: Moscow, Russia, 2016; ISBN 978-5-98877-061-9.

24. Рубан, Д.А. Водопады КакОбъектыГеологического Наследия. Вестник Томского Государственного Университета 2012, 363, 211-213. Available online: http:/ /journals.tsu.ru/uploads/import/876/ files/363-211.pdf (accessed on 12 June 2020). (In Russian)

25. Bathrellos, G.D.; Skilodimou, H.D. The contribution of geo-tourism to the geographic and regional development of Greece. In Proceedings of the 6th Pan-Hellenic Geographical Conference of the Hellenic Geographical Society, Thessaloniki, Greece, 3-6 October 2002; Volume I, pp. 455-462.

26. Bohle, M. Exploring Geoethics-Ethical Implications, Societal Contexts, and Professional Obligations of the Geosciences; Springer International Publishing: Cham, Switzerland, 2019; ISBN 1586 978-3-030-12009-2.

27. Di Capua, G.; Peppoloni, S. Defining Geoethics. Website of the IAPG—International Association for Promoting Geoethics. 2019. Available online: https:/ / www.geoethics.org/definition (accessed on 3 February 2021).

28. Martini, G. Geological Heritage and Geo-Tourism. Geological Heritage: Its Conservation and Management; Barettino, D., Wimbledon, W.A.P., Gallego, E., Eds.; Instituto Technológico Geominero de España: Madrid, Spain, 2000; pp. 147-156, ISBN 84-7840-417-1.

29. Carcavilla, L.; Díaz-Martínez, E.; García-Cortés, Á.; Vegas, J. Geoheritage and Geodiversity; Instituto Geológico y Minero de España (IGME): Madrid, Spain, 2019.

30. Gordon, J.E. Geoheritage, Geotourism and the Cultural Landscape: Enhancing the Visitor Experience and Promoting Geoconservation. Geosciences 2018, 8, 136. [CrossRef]

31. Gordon, J.E. Geoconservation principles and protected area management. Int. J. Geoheritage Parks 2020, 7, 199-210. [CrossRef]

32. Antić, A.; Peppoloni, S.; Di Capua, G. Applying the Values of Geoethics for Sustainable Speleotourism Development. Geoheritage 2020, 12, 1-9. [CrossRef]

33. Häggquist, E.; Söderholm, P. The economic value of geological information: Synthesis and directions for future research. Resour. Policy 2015, 43, 91-100. [CrossRef]

34. Peppoloni, S.; Di Capua, G. Geoethics: Ethical, Social, and Cultural Values in Geosciences Research, Practice, and Education. In Geoscience for the Public Good and Global Development: Toward a Sustainable Future, Geological Society of America, Special Papers; Wessel, G., Greenberg, J., Eds.; Geological Society of America: Boulder, CO, USA, 2016; pp. 17-21. [CrossRef]

35. Galanakis, D. Neotectonic and Stratihraphic of the Neogene-Quaternary Sediments of Almyros-Pagasitikos, Pilio, Oreoi-Trikeri and Maliakos Basins. Ph.D. Thesis, Department of Geology, Aristotle University of Thessaloniki, Thessaloniki, Greece, 1997. (In Greek) [CrossRef]

36. Hellenic Ministry of Environment and Energy—Special Secretariat for Water. (EL08). (In Greek). Available online: http:/ /wfdver.ypeka. gr/wp-content/uploads/2017/05/EL08_1REV_P09_Mitrwo_Prostatevomenwn_v01.pdf (accessed on 12 June 2021).

37. Filippidis, A. Landslide Susceptibility Evaluation in the Region of Pelion, Magnesia County. Master's Thesis, Department of Geology and Geoenvironment, National and Kapodistrian University of Athens, Athens, Greece, 2015. Available online: https:/ / pergamos.lib.uoa.gr/uoa/dl/object/1317155 (accessed on 5 June 2021). (In Greek)

38. Georgiades, A. Contribution a l' étude du cristallo-phyllien du Pélion. Prakt. Akad. Athenon 1937, 12, 60-70.

39. Georgiades, A. Tuff augitique métamorphisé ou la Phyllode augitique de Makrinitsa. Prakt. Akad. Athenon 1942, 17, $199-201$.

40. Georgiades, A. Contribution a l' étude des granites de la Grèce du Nord. Prakt. Akad. Athenon 1954, $29,326-336$.

41. Flint, R.F.; Skinner, B. Physica1 Geology; John Wiley and Sons: New York, NY, USA, 1974; ISBN 0471264407.

42. Alexouli-Livaditi, A. General Geology_Geomorphology; National Technical University of Athens: Athens, Greece, 2008. (In Greek)

43. Karymbalis, E. Coastal Geomorphology; ION Publishing Group: Athens, Greece, 2010; ISBN 978-960-411-714-7. (In Greek)

44. Arnott, R.D. Introduction to Coastal Processes and Geomorphology; Cambridge University Press: New York, NY, USA, 2010.

45. Kokkinou, E. Environmental Geology and Geotechnology; National Technical University of Athens, Hellenic Academic Libraries Link: Athens, Greece, 2015; ISBN 978-960-603-036-9. Available online: http:/ / hdl.handle.net/11419/325 (accessed on 18 June 2021). (In Greek)

46. Earle, S. Physical Geology; BC Campus: Victoria, BC, Canada, 2015. Available online: https://opentextbc.ca/geology/ (accessed on 4 June 2021).

47. Seitz, R.D.; Wennhage, H.; Bergström, U.; Lipcius, R.N.; Ysebaert, T. Ecological value of coastal habitats for commercially and ecologically important species. ICES J. Mar. Sci. 2014, 71, 648-665. [CrossRef]

48. Dietrich, V.; Lagios, E.; Zographos, G. Supplementary Section to 12,800 Years Ago, Hellas and the World on Fire and Flood. J. Geogr. Earth Sci. 2019, 7, 78-109. Available online: https://www.researchgate.net/publication/335560419_12800_years_ago_ Hellas_and_the_World_on_Fire_and_Flood (accessed on 10 July 2021). [CrossRef]

49. Aston, E. Thetis and Cheiron in Thessaly. Kernos 2009, 22, 83-107. Available online: Journals.openedition.org/kernos/1769 (accessed on 14 July 2021). [CrossRef] 
50. Vouzaxakis, K. South Pelion Research, Excavations, Perspectives. In Proceedings of the Archaeological Work in Thessaly and Sterea Ellada, Volos, Greece, 15-18 March 2012; Volume 1.

51. Ragkou, P. Didactic of Environmental Education; Aristotle University of Thessaloniki: Thessaloniki, Greece, 2014. Available online: http:/ / eclass.auth.gr/courses/OCRS439/ (accessed on 9 July 2021).

52. Fermeli, G.; Markopoulou-Diakantoni, A. Selecting Pedagogical Geotopes in Urban Environment. Bull. Geol. Soc. Greece 2004, 36, 649-658. [CrossRef]

53. Iliopoulou, I. Storyline; Elati: Piraeus, Greece, 2005; ISBN 9789606657009.

54. Johnson, D.W.; Johnson, R.T. Cooperation and Competition: Theory and Research; Interaction Book Company: Edina, MN, USA, 1989; ISBN 093960310.

55. Johnson, D.W.; Johnson, R.; Holubec, E. Circles of Learning: Cooperation in the Classroom; Interaction Book Company: Edina, MN, USA, 1990.

56. Brown, J.S.; Collins, A.; Duguid, S. Situated cognition and the culture of learning. Educ. Res. 1989, 18, 32-42. [CrossRef]

57. Matsagouras, H. Theory and Practice of Teaching; Teaching Strategies, Critical Thinking in Teaching Practice; Gutenberg: Athens, Greece, 2005; Volume 1, ISBN 978-960-01-0659-2. (In Greek)

58. Savelides, S.C.; Fasouraki, R.; Georgousis, E.; Kolokotroni, K.; Savelidi, M.S. Interdisciplinary Educational Approach STEM and HASS Knowledge Fields Using ICTs Support. Case of an Application for a Pilot Experiment. Eur. J. Eng. Res. Sci. 2020, 33-42. [CrossRef]

59. Georgousis, E.; Savelides, S.; Drinia, H. Interdisciplinary Approach Research of STEM\&HASS Educational Objects in Confronting Complex Environmental Problems. In Proceedings of the 8th Conference on Environmental Education for Sustainability in the Age of Climate Change, Patra, Greece, 11-13 September 2020. (In Greek)

60. Doukakis, S.; Alexopoulos, E.C.; Niari, M. The role of educational neuroscience in synchronous online learning. Open Educ. J. Open Distance Educ. Educ. Technol. 2021, 17, 168-183.

61. Schellenberg, S. Perceptual Capacities, Knowledge, and Gettier Cases. In Explaining Knowledge: New Essays on the Gettier Problem; Borges, R., de Almeida, C., Klein, P.D., Eds.; Oxford University Press: Oxford, UK, 2017; pp. 74-95. Available online: https:/ / core.ac.uk/download/pdf/326513231.pdf (accessed on 23 April 2020).

62. Braun, V.; Clarke, V. Thematic analysis. In APA Handbook of Research Methods in Psychology; Research Designs: Quantitative, Qualitative, Neuropsychological, and Biological; Cooper, H., Camic, P.M., Long, D.L., Panter, A.T., Rindskopf, D., Sher, K.J., Eds.; American Psychological Association: Washington, DC, USA, 2012; Volume 2, pp. 57-71. [CrossRef]

63. Braun, V.; Clarke, V. Can I use TA? Should I use TA? Should I not use TA? Comparing reflexive thematic analysis and other pattern-based qualitative analytic approaches. Couns. Psychother. Res. 2021, 21, 37-47. [CrossRef]

64. Braun, V.; Clarke, V. (Mis)conceptualising themes, thematic analysis, and other problems with Fugard and Potts' (2015) samplesize tool for thematic analysis. Int. J. Soc. Res. Methodol. 2016, 19, 739-743. [CrossRef]

65. Fugard, A.J.; Potts, H.W. Supporting thinking on sample sizes for thematic analyses: A quantitative tool. Int. J. Soc. Res. Methodol. Theory Pract. 2015, 18, 669-684. [CrossRef]

66. Bryman, A. Social Research Methods; Oxford University Press: Oxford, UK, 2012.

67. Issari, P.; Pourkos, M. Qualitative Research Methods in Psychology and Education; Hellenic Academic Libraries Link: Athens, Greece, 2015. Available online: https:/ / repository.kallipos.gr/handle/11419/5826 (accessed on 4 July 2021). (In Greek)

68. Di Cicco-Bloom, B.; Crabtree, B.F. The qualitative research interview. Med. Educ. 2006, 40, 314-321. [CrossRef]

69. UNESCO World Heritage Centre. Operational Guidelines for the Implementation of the World Heritage Convention; UNESCO: Paris, France, 1999.

70. Dingwall, P.R. Legislation and international agreements: The integration of the geological heritage in nature conservation policies. In Geological Heritage: Its Conservation and Management; Barettino, D., Wimbledon, W.P., Gallego, E., Eds.; Instituto Tecnológico Geominero de España: Madrid, Spain, 2000; pp. 15-28.

71. Goldman, A.H. Aesthetic qualities and aesthetic value. J. Philos. 1990, 87, 23-37. [CrossRef]

72. Stephenson, J. The Cultural Values Model: An integrated approach to values in landscapes. Landsc. Urban Plan. 2008, 84, 127-139. [CrossRef]

73. Cordell, H.K.; Murphy, D.; Riitters, K.H.; Harvard, J.E. The natural ecological value of wilderness. In The Multiple Values of Wilderness; Cordell, H.K., Bergstrom, J.C., Bowker, J.M., Eds.; Venture Publishing Inc.: Alberta, AB, Canada, 2005; pp. 205-249.

74. Oxford University Press. Report of the World Commission on Environment and Development: Our Common Future; Oxford University Press: Oxford, UK, 1987.

75. Maxwell, J. Understanding and validity in qualitative research. Harv. Educ. Rev. 1992, 62, 279-301. [CrossRef]

76. Aragão, A. Relational Value as an Argument to Protect Geological and Hydrogeologic Goods. In Advances in Geoethics and Groundwater Management: Theory and Practice for a Sustainable Development; Springer: Cham, Switzerland, 2021; pp. 3-7.

77. Mikhailenko, A.V.; Nazarenko, O.V.; Ruban, D.A.; Zayats, P.P. Aesthetics-Based Classification of Geological Structures in Outcrops for Geotourism Purposes: A Tentative Proposal. Geologos 2017, 23, 45-52. Available online: http:/ /www.geologos.com.pl/pdf/ Geologos-23-1-Mikhailenko.pdf (accessed on 6 September 2021). [CrossRef]

78. Zhou, A.; Liu, H.; Zhang, S.; Ouyang, J. Evaluation and Design Method for Product Form Aesthetics Based on Deep Learning. IEEE Access 2021, 9, 108992-109003. [CrossRef] 
79. Čiegis, R.; Gavenauskas, A.; Petkevičiūte, N.; Štreimikiene, D. Ethical values and sustainable development: Lithuanian experience in the context of globalisation. Technol. Econ. Dev. Econ. 2008, 14, 29-37. [CrossRef]

80. Curto, R.; Barreca, A.; Coscia, C.; Ferrando, D.G.; Fregonara, E.; Rolando, D. The Active Role of Students, Teachers, and Stakeholders in Managing Economic and Cultural Value, Urban and Built Heritage. Interdiscip. J. Probl.-Based Learn. 2021, 15. [CrossRef]

81. Thomas, A. Importance and Threats to Biodiversity. 2021. Available online: https://web.sol.du.ac.in/my_modules/type/cbcs41-2/data/root/B.Com/Semester\%202/ABILITY-ENHANCEMENT\%20COMPULSORY\%20COURSE-AECC/EVS\%20-\%20 English\%20Medium/Lesson\%20-\%201\%20to\%203.pdf (accessed on 3 September 2021).

82. Kates, R.W.; Parris, T.M.; Leiserowitz, A.A. What is Sustainable Development? Goals, Indicators, Values and Practice. Environ. Sci. Policy Sustain. Dev. 2005, 47, 8-21. [CrossRef]

83. Redclift, M. Sustainable Development: Needs, Values, Rights. Environ. Values 1993, 2, 3-20. [CrossRef]

84. Velenturf, A.P.; Purnell, P. Principles for a Sustainable Circular Economy. Sustain. Prod. Consum. 2021, 27, 1437-1457. [CrossRef]

85. Gkargkavouzi, A.; Halkos, G.; Matsiori, S. Development and validation of a Scale for measuring Multiple Motives toward Environmental Protection (MEPS). Glob. Environ. Chang. 2019, 58, 101971. [CrossRef]

86. Clayton, S.; Karazsia, B.T. Development and validation of a measure of climate change anxiety. J. Environ. Psychol. 2020, 69, 101434. [CrossRef]

87. Scopigno, R. Mixing Visual Media for Cultural Heritage. In Proceedings of the First International Conference on Emerging Technologies and the Digital Transformation of Museums and Heritage Sites, RISE IMET, Nicosia, Cyprus, 2-4 June 2021; Shehade, M., Stylianou-Lambert, T., Eds.; Springer: Cham, Switzerland, 2021; pp. 297-315. 